\title{
OPTIMALISASI KEMAMPUAN GURU RUMPUN IPA DALAM MENDESAIN RPP MODEL INKUIRI MENGGUNAKAN SUPERVISI BERBASIS COACHING
}

\author{
OPTIMIZATION OF TEACHER'S ABILITY IPA \\ DESIGNING RPP INQUIRY MODEL USING \\ COACHING-BASED SUPERVISION
}

\author{
Jefri Soni Silitonga* \\ SMA Negeri Unggul Aceh Timur
}

Diterima: Maret 2020; Disetujui: Maret 2020; Dipublish: Maret 2020

*Coresponding Email: iefsilitonga@gmail.com

\begin{abstract}
Abstrak
Kemampuan merencanakan pembelajaran merupakan salah satu standar bagi guru untuk melaksanakan pengajaran. Oleh karena itu maka perlu dilakukan pendampingan berupa supervisi akademik secara kontinu, berkesinambungan serta konstruktif dan kreatif agar guru terlibat secara aktif menciptakan suasana belajar yang mampu membangkitkan kreativitas siswa. Tujuan penelitian ini adalah untuk mengungkapkan kesesuaian kemampuan guru rumpun mata pelajaran IPA dalam menerapkan RPP model inkuiri dengan menggunakan supervisi akademik berbasis coaching. Metode penelitian yang digunakan adalah action research dengan model Kemmis \& Taggart. Pencapaian hasil penelitian dilaksanakan dengan dua (2) siklus. Hasil penelitian siklus I menunjukkan bahwa rerata kemampuan guru rumpun IPA dalam menyusun RPP model inkuiri adalah $72,62 \%$ dan meningkat pada siklus II menjadi $91,67 \%$. Hal ini merupakan dampak dari pendampingan yang dilakukan oleh peneliti dengan menerapkan supervisi akademik berbasis coaching.
\end{abstract}

Kata Kunci: Supervisi akademik, Coaching, Guru, IPA

\begin{abstract}
The ability to plan to learn is one of the standards for teachers to perform the teaching. Therefore, it is necessary to do mentoring in the form of continuous, continuous and constructive and creative academic supervision so that teachers actively engaged in creating a learning atmosphere that can inspire students ' creativity. This research aims to reveal the suitability of the teachers' skills of the IPA subjects in implementing the RPP inquiry model by using coaching-based academic supervision. The research method used is action research with Kemmis \& Taggart model. The achievement of research results is carried out by two (2) cycles. The results of the cycle I study showed that the average of IPA's teachers ' ability in drafting RPP Model inquiry was 72,62\% and increased in cycle II to 91,67\%. This is the impact of mentoring conducted by researchers by implementing coaching-based academic supervision.
\end{abstract}

Keywords: Academic supervision, Couching, teachers, Sciences

How to Cite: Silitonga, Jefri. S. (2020). Optimalisasi Kemampuan Guru Rumpun IPA dalam Mendesain RPP Model Inkuiri Menggunakan Supervisi Berbasis Coaching. Journal of Natural Sciences. Vol 1 (1): 1-16 
Silitonga, Jefri. S. Optimalisasi Kemampuan Guru Rumpun IPA dalam Mendesain RPP Model Inkuiri Menggunakan Supervisi Berbasis Coaching

\section{PENDAHULUAN}

Sanjaya (2011) menyatakan bahwa sebaik dan seideal apapun kurikulum pendidikan, didukung oleh sarana dan prasarana pendidikan yang lengkap, namun apabila tidak diimbangi dengan kemampuan guru dalam mengimplementasikannya, maka semuanya akan kurang bermakna. Sehingga sudah seharusnya menjadi perhatian bagi semua pihak untuk menitikberatkan pada aspek pengembangan kemampuan guru. Karena guru merupakan tombak kepemimpinan di dalam kelas mengajar. Salah satu cara untuk mengembangkan kemampuan guru adalah dengan memberikan pendampingan berupa supervisi akademis yang memberikan peluang bagi guru untuk mengembangkan kemampuan mengajarnya lebih bersifat kolaboratif, reflektif, dan dilaksanakan secara berkesinambungan.

Guru, khususnya di SMAN Unggul Aceh Timur dalam periode satu tahun pelajaran ataupun satu semester mendapatkan jadwal supervisi dari kepala sekolah. Namun, acapkali beberapa jadwal akan tergeser dari waktunya dan pelaksanaan supervisi kurang memenuhi standarnya. Demikian juga dengan supervisi yang dilakukan dari pengawas sekolah yang tidak menyeluruh dan tidak rutin sehingga terbatas pada pertemuan biasa secara umum dan ataupun kunjungan kelas secara mendadak terhadap guru. Beberapa guru juga secara rutin terlibat dalam berbagai bimbingan teknis melalui pelatihan, workshop, kegiatan MGMP secara rutin, diskusi dengan sejawat ataupun studi literasi dari buku dan internet. Namun hal ini belum maksimal.

Widodo (2011) mengungkapkan bahwa kendala yang dihadapi dalam penerapan terkait dengan isi pelatihan/penataran adalah kurang sesuainya materi pelatihan dengan kebutuhan lapangan, sebagian besar belum diikuti dengan monitoring dan evaluasi yang memadai. Selain itu, tidak ada evaluasi, dukungan nyata dari sekolah (waktu, sarana, dan dana) juga kurang memadai.

Soetjipto \& Kosasi (1999) menjelaskan bahwa seyogyanya supervisi pengajaran mengkonsentrasikan kewasannya untuk membantu guru dalam proses perbaikan pengajaran. Agar apa yang diungkapkan oleh Aqib, Z \& Rohmanto (2007) tentang tiga (3) pilar utama yang menunjukkan bahwa guru telah mampu bekerja secara profesional dalam melaksanakan tugas kependidikan adalah (a) menguasai materi pembelajaran, (b) profesional dalam menyampaikan materi pembelajaran kepada siswa, dan (c) berkepribadian matang terpenuhi dengan baik. 
Perencanaan, pelaksanaan, dan penilaian dalam proses pembelajaran perlu diawasi dan diperbaiki bahkan dikembangkan. Pelaksanaan pengawasan proses pembelajaran dilakukan melalui supervisi, baik oleh kepala sekolah ataupun pengawas sekolah.

Sagala (2010) menekankan pentingnya supervisi terhadap pembelajaran. Ia menambahkan bahwa supervisi yang dilaksanakan di sekolah harus memberikan peluang dan kesempatan kepada guru untuk mengembangkan kemampuan profesional mereka. Kemampuan profesional ini tercermin pada kemampuan guru memberikan bantuan belajar kepada siswanya. Sehingga terjadi perubahan perilaku. Supervisi harus dilaksanakan oleh supervisor secara konstruktif dan kreatif dengan cara mendorong inisiatif guru untuk ikut aktif menciptakan suasana kondusif yang dapat membangkitkan suasana kreativitas siswa dalam belajar.

Terutama pada mata pelajaran IPA yang berkaitan dengan cara mencari tahu tentang alam secara sistematis, sehingga IPA bukan hanya kumpulan pengetahuan yang berupa fakta-fakta, konsep-konsep, atau prinsip-prinsip saja tetapi juga merupakan proses penemuan. Pembelajaran IPA diharapkan dapat menjadi wahana bagi siswa untuk mempelajari diri sendiri dan alam sekitar, serta prospek pengembangan lebih lanjut dalam menerapkannya dalam kehidupan sehari-hari. Proses pembelajarannya menekankan pada pemberian pengalaman langsung untuk mengembangkan kompetensi agar menjelajahi dan memahami alam sekitar secara ilmiah.

Sejalan dengan hal itu, National Research Council (Witarsa, 2011) menyebutkan enam (6) standar guru dalam melaksanakan pembelajaran sains sebagai berikut: (1) Dapat merencanakan pembelajaran sains yang berbasis inkuiri; (2) Melaksanakan pembelajaran sains yang mengarahkan dan memfasilitasi siswa dalam belajar; (3) Melaksanakan penilaian yang disesuaikan dengan kegiatan guru mengajar dan sesuai dengan pembelajaran siswa; (4) Mengembangkan pembelajaran dari lingkungan dimana siswa belajar; (5) Menciptakan masyarakat pembelajar sains; dan (6) Merencanakan dan mengembangkan pembelajaran dari program sains sekolah.

Proses pembelajaran IPA di Indonesia masih terlalu berorientasi terhadap penguasaan teori dan hafalan yang menyebabkan kemampuan belajar peserta didik menjadi terhambat. Metode pembelajaran yang terlalu berorientasi kepada guru (teacher centered) cenderung mengabaikan hak-hak dan kebutuhan, serta pertumbuhan 
Silitonga, Jefri. S. Optimalisasi Kemampuan Guru Rumpun IPA dalam Mendesain RPP Model Inkuiri Menggunakan Supervisi Berbasis Coaching

dan perkembangan anak, sehingga proses pembelajaran yang menyenangkan, mengasyikkan, dan mencerdaskan kurang optimal (Puskur Balitbang Depdiknas, 2007).

Oleh karenanya, perlu dilakukan pemilihan model pembelajaran yang sesuai untuk diimplementasikan pada ruang kelas. Salah satu model pembelajaran yang sesuai adalah model inkuiri. Hal ini sesuai dengan pendapat Trianto (2011). yang menyatakan bahwa pembelajaran IPA diarahkan untuk inkuiri dan berbuat, sehingga dapat membantu siswa untuk memperoleh pemahaman yang lebih mendalam tentang alam sekitar.

Model inkuiri adalah suatu rancangan kegiatan pembelajaran yang digunakan dalam pembelajaran dan mengacu pada suatu cara untuk mempertanyakan, mencari pengetahuan atau informasi, atau mempelajari suatu gejala (Koes, 2003). Joyce (2011) menyatakan tujuan umum inkuiri adalah membantu siswa mengembangkan displin intelektual dan keterampilan yang mumpuni untuk meningkatkan pertanyaanpertanyaan dan pencarian jawaban yang terpendam dari rasa keingintahuan mereka.

Salah satu kewajiban guru sebelum melaksanakan pembelajaran adalah menyusun perangkat pembelajaran. RPP merupakan pedoman dan arahan tentang kegiatan yang akan dilakukan selama proses pembelajaran oleh guru dari awal sampai dengan berakhirnya pembelajaran. Dalam arti bahwa agar apa yang diinginkan setelah proses pembelajaran berlangsung para peserta didik dapat mencapai tujuan-tujuan pembelajaran tertentu sebagaimana yang ditentukan. Jika proses pembelajaran yang dilakukan tidak sesuai dengan apa yang telah direncanakan dalam RPP sebelumnya, tentu sudah bisa dipastikan bahwa proses pembelajaran akan berjalan tanpa arah dan tujuan yang jelas (Suhatman, 2013).

Sergiovani, T dan Starratt (2007) menyatakan "Clinical supervision and coaching as ways to help teachers research their practice. Clinical supervision and coaching are good examples of a balanced approach to supervision-informal to be responsive to teacher's need and interests and formal enough to ensure that agreed-upon standards of good teaching are also given attention. Coaching takes a number of different forms but at its root share the posture of clinical supervisions".

Supervisi klinis dan coaching sebagai arah untuk membantu guru-guru meneliti pembelajaran mereka. Supervisi klinis dan coaching merupakan contoh pendekatan yang baik dalam supervisi, secara informal memahami kebutuhan dan ketertarikan guru dan cukup formal untuk menjamin standar kesepakatan pembelajaran yang baik untuk 
diperhatikan. Coaching memiliki format yang berbeda namun mirip dengan susunan pada supervisi klinis.

Menurut Fischler (2004) (Riandi, 2008) program coaching merupakan suatu program yang dirancang untuk membantu guru menemukan kelebihan dan kekurangannya serta memberikan saran untuk meningkatkan kemampuan profesional guru. Coaching bertujuan untuk mendorong mereka agar dapat mengembangkan diri dan memperbaiki kinerjanya melalui refleksi bagaimana mereka menerapkan suatu keterampilan dan pengetahuan tertentu dalam menangani sasaran kerja yang telah ditetapkan sebelumnya.

Duit, Widodo, dan Mueller (2007) (Riandi, 2008) selanjutnya menyatakan bahwa Coaching bisa membantu coachee yakni guru untuk menyadari kelemahan dalam dirinya yang perlu diperbaiki, mendapatkan ide untuk memperbaiki kelemahan yang dimilikinya, dan memotivasi mereka untuk meningkatkan kemampuan diri.

Pelaksanaan coaching di sekolah oleh pengawas, kepala sekolah dan guru sangat penting dilakukan dalam mendukung implementasi kurikulum 2013. Agar pelaksanaannya berjalan optimal maka coaching harus dilakukan dengan menggunakan prinsip kerjasama, berbagi, menjembatani gap, formal dan informal, kemitraan, motivasi, fokus, saling percaya, dan rasa hormat (Kemdikbud, 2013).

\section{METODE PENELITIAN}

Penelitian dilaksanakan di SMAN Unggul Aceh Timur. Adapun subyek penelitian adalah guru mata pelajaran rumpun IPA yang berjumlah tiga (3) orang, yakni:

Tabel 1. Data Subjek Penelitian

\begin{tabular}{cccc}
\hline No & Mata Pelajaran & Kode Guru & Jumlah \\
\hline 1 & Biologi & G1 & 1 Orang \\
2 & Fisika & G2 & 1 Orang \\
3 & Kimia & G3 & 1 Orang \\
\hline & Total & & 3 Orang \\
\hline
\end{tabular}


Silitonga, Jefri. S. Optimalisasi Kemampuan Guru Rumpun IPA dalam Mendesain RPP Model Inkuiri Menggunakan Supervisi Berbasis Coaching

Model action research yang digunakan dalam penelitian ini adalah model yang dikembangkan oleh Kemmis dan Mc Taggart. Model Kemmis dan Mc Taggart merupakan pengembangan dari model yang dikenalkan oleh Kurt Lewin. Hanya saja, komponen acting (tindakan) dengan observing (pengamatan) dijadikan sebagai satu kesatuan (Sukardi, 2005).
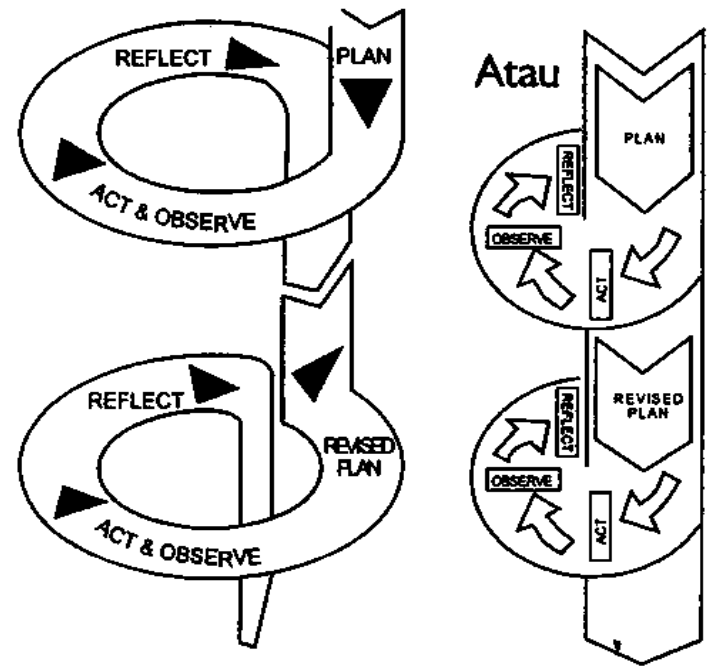

Gambar 1. Model Penelitian Tindakan Kemmis dan Mc Taggart

Tahapan dalam penelitian tindakan ini dilaksanakan dalam 2 (dua) siklus yang selanjutnya dijabarkan sebagai berikut:

\section{Perencanaan (Plan)}

Pada tahapan perencanaan mencakup tahapan pertama, kedua, dan ketiga pada langkah coaching yakni klarifikasi tujuan coaching, menyepakati kebutuhan pengembangan tertentu dan merumuskan pelaksanaan coaching secara terperinci. Tahapan ini dilakukan dengan langkah-langkah sebagai berikut:

a. Menyampaikan tujuan pelaksanaan coaching dan langkah-langkah (rencana kerja) yang digunakan selama coaching kepada guru rumpun IPA.

b. Membagi fokus program coaching pada 3 topik yaitu konsep model inkuiri, penyusunan RPP model inkuiri, dan prosedur pelaksanaan model inkuiri.

c. Menentukan jadwal dan tempat pelaksanaan coaching.

d. Diskusi dan wawancara dengan subjek penelitian tentang deskripsi diri guru dan pengalaman pelatihan guru.

e. Memberikan bahan bacaan dan contoh Rencana Pelaksanan Pembelajaran (RPP) mengenai model inkuiri kepada guru. 
2. Tindakan (Act) dan Pengamatan (Observe)

Dalam tindakan dan pengamatan dilakukan sesuai dengan tahapan keempat dan kelima coaching (melaksanakan tugas/ aktivitas kemudian meninjau kembali aktivitas dan merencanakan peningkatan kinerja) yang dijabarkan sebagai berikut:

a. Melaksanakan diskusi tentang konsep model inkuiri, menyusun RPP dengan model inkuiri, dan mereview langkah-langkah, bahan ajar, media, dan penilaian yang akan digunakan dalam pembelajaran inkuiri.

b. Mengobservasi guru di kelas untuk melaksanakan model inkuiri dengan bantuan observer.

c. Mengumpulkan data kemampuan guru dalam melaksanakan model inkuiri melalui lembar observasi dan dokumentasi melalui perekaman video.

d. Memberikan hasil rekaman video kepada guru untuk dinilai sendiri dengan menggunakan lembar observasi.

e. Melaksanakan kegiatan percakapan umpan balik (refleksi) setelah kegiatan pembelajaran dilakukan, berdasarkan data observasi dan dokumentasi.

f. Memberikan tes pengetahuan konsep model inkuiri.

3. Refleksi (Reflect)

Pada tahap refleksi merupakan tahapan coaching yang keenam yakni mengakhiri kegiatan coaching, peneliti melaksanakan langkah-langkah di bawah ini untuk mempertimbangkan apakah coaching bisa diakhiri ataupun belum. Langkah yang dilakukan adalah sebagai berikut:

a. Menganalisis hasil observasi pembelajaran guru dalam satu siklus

b. Menganalisis hasil kegiatan umpan balik dengan guru pada pertemuan sebelumnya.

c. Menerima masukan dari observer kegiatan mengenai tahapan coaching yang telah dilaksanakan.

d. Membandingkan hasil analisis data dengan indikator keberhasilan tindakan, untuk menentukan tahapan coaching pada siklus selanjutnya

Data penelitian akan dikumpulkan dengan cara observasi terhadap RPP yang telah disusun oleh guru rumpun IPA dan wawancara kepada mereka. Data yang telah dikumpulkan dianalisis dengan membandingkan data sebelum tindakan dengan data setelah tindakan: 
Silitonga, Jefri. S. Optimalisasi Kemampuan Guru Rumpun IPA dalam Mendesain RPP Model Inkuiri Menggunakan Supervisi Berbasis Coaching

a. Rerata kemampuan guru menyusun RPP model inkuiri diukur peningkatannya dengan menggunakan persentase (\%) pencapaian kesesuaian.

b. Hasil observasi kemampuan guru dalam melaksanakan model inkuiri diukur peningkatannya dengan menggunakan persentase (\%) pencapaian kesesuaian.

c. Penelitian tindakan ini dianggap sudah selesai setelah permasalahan yang ihadapi oleh guru terpecahkan. Dengan indikator pencapaian 85\% guru rumpun IPA telah berhasil menyusun RPP dengan model inkuiri.

\section{HASIL DAN PEMBAHASAN}

\section{Analisis Data Observasi}

Berdasarkan hasil telaah terhadap RPP yang telah disusun oleh guru rumpun mata pelajaran IPA kelas X di SMAN Unggul Aceh Timur diperoleh hasil sebagai berikut:

Tabel 1. Persentase Rerata Kemampuan Guru Menyusun RPP

\begin{tabular}{clcr}
\hline \multirow{2}{*}{ No } & \multicolumn{1}{c}{ Indikator Kesesuaian } & \multicolumn{2}{c}{ Rata-rata } \\
& \multicolumn{1}{c}{ Skor } & \multicolumn{1}{c}{$\%$} \\
\hline 1 & Perumusan tujuan pembelajaran & 3.20 & 80.00 \\
2 & Pengorganisasian bahan ajar & 1.60 & 40.00 \\
3 & Penentuan model/strategi pembelajaran & 4.00 & 100.00 \\
4 & Penentuan langkah-langkah pembelajaran & 1.60 & 40.00 \\
5 & Penentuan alokasi waktu & 2.00 & 50.00 \\
6 & Pemilihan sumber, media, dan alat & 2.60 & 65.00 \\
7 & Penentuan bentuk, prosedur, dan alat & 2.00 & 50.00 \\
\hline \multicolumn{3}{c}{ penilaian } & 17.00 \\
\hline \multicolumn{3}{c}{ Skor maksimal ideal = 28 kesesuaian } \\
\hline
\end{tabular}

Berdasarkan data tersebut diketahui bahwa rerata kesesuaian kemampuan guru dalam menyusun RPP adalah 60.71 \% dengan rincian sebagai berikut:

1. Indikator terendah yaitu pengorganisasian bahan ajar (40\%) dan indikator penentuan alokasi waktu (40\%).

2. Sedangkan untuk menentukan model/strategi pembelajaran sudah sangat baik karena mencapai $100 \%$.

Data pada tabel 1, dapat divisualisasikan pada diagram berikut ini: 


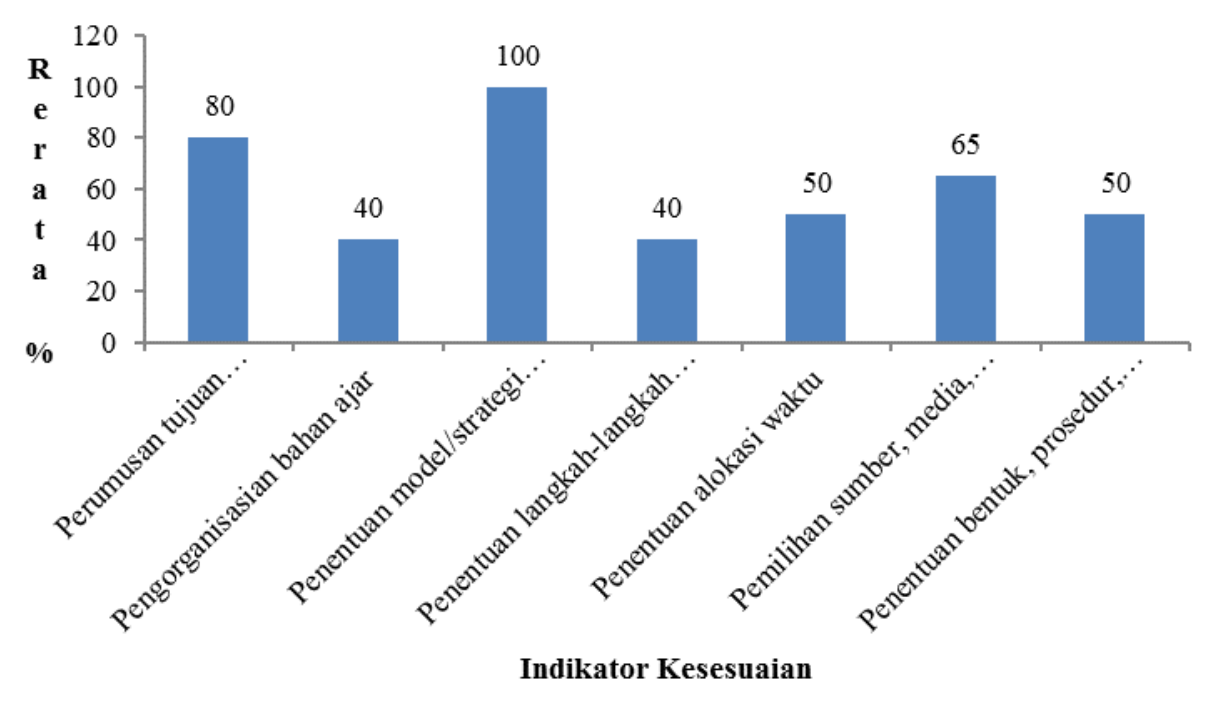

Gambar 1. Persentase Kesesuaian Kemampuan Guru Menyusun RPP

\section{Analisis Data Penelitian Siklus I}

Rangkaian tahapan supervisi akademik berbasis coaching dilakukan sebagai berikut:

\section{a. Perencanaan}

Perencanaan tindakan dilaksanakan selama empat (4) hari dengan program coaching memberikan bantuan berupa:

1. Pemaparan tujuan dan langkah-langkah coaching kepada kepala sekolah/wakil kurikulum, dan guru rumpun mata pelajaran IPA Kelas X.

2. Sharing pengalaman kerja guru selama satu (1) semester tentang penerapan kurikulum 2013.

3. Mendiskusikan pengalaman kerja guru selama 1 semester tentang penerapan kurikulum 2013.

4. Pemaparan konsep model inkuiri dengan memberikan bahan bacaan/literature, contoh RPP tentang strategi pembelajaran inkuiri, dan skenario pembelajaran inkuiri.

5. Berdiskusi dengan guru tentang rincian jadwal mengajar untuk penyesuaian program coaching.

Hasil diskusi pada tahap perencanaan ini diperoleh jadwal perencanan program coaching yang tertuang dalam Rencana Kegiatan Pendampingan (RKP). Jadwal 
Silitonga, Jefri. S. Optimalisasi Kemampuan Guru Rumpun IPA dalam Mendesain RPP Model Inkuiri Menggunakan Supervisi Berbasis Coaching

pertemuan program coaching disesuaikan dengan jadwal kehadiran guru di sekolah dan tidak mengganggu tugas guru di kelas.

b. Tindakan dan Observasi

Pelaksanaan penelitian dilakukan dengan rangkaian tindakan sebagai berikut:

1. Melaksanakan diskusi tentang konsep model inkuiri, menyusun RPP, mereview langkah-langkah, bahan ajar, media, dan penilaian yang akan digunakan dalam pembelajaran inkuiri. Pembagian jadwal pertemuan terhadap 3 orang guru subjek selanjutnya dirincikan pada tabel 2 berikut ini:

Tabel 2. Tindakan dan Observasi coaching siklus I

\begin{tabular}{|c|c|c|c|}
\hline Pert & $\begin{array}{l}\text { Kode } \\
\text { Guru }\end{array}$ & Fokus Coaching & $\begin{array}{c}\text { Hasil } \\
\text { Kesepakatan }\end{array}$ \\
\hline \multirow[t]{4}{*}{1} & G1 & a. Diskusi konsep Model inkuiri & Guru memilih materi dan menentukan \\
\hline & G2 & b. Langkah-langkah pembelajaran & indikator pembelajaran \\
\hline & G3 & c. Bahan ajar yang sesuai dengan & Guru menyusun RPP \\
\hline & & model inkuiri & Guru mempersiapkan bahan ajar/LKS \\
\hline \multirow[t]{3}{*}{2} & G1 & Diskusi rancangan permasalahan/ & Revisi skenario \\
\hline & G2 & hipotesis pembelajaran, metode & permasalahan/hipotesis pembelajaran \\
\hline & G3 & $\begin{array}{l}\text { pembelajaran, bahan ajar, dan media yang } \\
\text { telah dibuat guru }\end{array}$ & $\begin{array}{l}\text { dan Revisi Bahan ajar dan media yang } \\
\text { disusun guru }\end{array}$ \\
\hline \multirow[t]{3}{*}{3} & G1 & Diskusi tentang instrumen penilaian yang & Guru menyerahkan fotocopi RPP dan \\
\hline & G2 & digunakan guru dan mengulas balik RPP & bahan ajar yang digunakan oleh guru. \\
\hline & G3 & yang akan diterapkan oleh guru & \\
\hline
\end{tabular}

Pada tahap ini, beberapa hal yang menjadi bahan observasi adalah:

a. Melakukan observasi pembelajaran dengan menggunakan model inkuiri di kelas $\mathrm{X}$ sesuai dengan jadwal tatap muka guru. Observasi dilakukan oleh peneliti bersama observer disertai dengan perekaman kegiatan pembelajaran dengan menggunakan kamera video.

b. Memberikan hasil rekaman video kepada guru, untuk dinilai dengan menggunakan lembar observasi yang sama dengan observer.

c. Meminta guru untuk menyelesaikan penilaian hasil belajar siswa, untuk digunakan sebagai pertimbangan rencana pembelajaran berikutnya.

d. Melaksanakan refleksi/ umpan balik dengan guru berdasarkan data observasi yang telah ada, dan merencanakan perbaikan ke depan. Dari hasil kegiatan umpan balik dengan para guru diketahui bahwa;

1) Guru masih merasa bingung pada saat memaparkan masalah yang sesuai dengan konsep/tujuan pembelajaran, sehingga pada saat tahapan 
merumuskan hipotesis terlupakan untuk diarahkan ke siswa ataupun guru langsung menyebutkan hipotesis tersebut.

2) Guru merasa kurang memiliki sumber ataupun wawasan dalam hal mengkaitkan konsep materi pelajaran, sehingga berdampak pada kurang menariknya contoh masalah yang disampaikan.

3) Guru masih melihat bahwa siswa masih terkesan kaku dalam mengikuti pola strategi pembelajaran yang diterapkan guru, sehingga tampak siswa yang masih malu-malu dan dalam beraktivitas untuk mencari data.

4) Guru merencanakan untuk menggunakan bantuan media komputer untuk memberikan daya tarik pada saat penyampaian permasalahan dan melakukan demonstrasi sederhana sebelum merumuskan masalah.

\section{Refleksi}

Kegiatan refleksi dilakukan setelah seluruh tahapan utama kegiatan coaching selesai. Berdasarkan hasil pengamatan dan catatan selama berlangsungnya siklus I, peneliti mengadakan refleksi sebagai berikut:

a. Hasil telaah kemampuan guru menyusun RPP pada siklus I disajikan pada tabel berikut :

Tabel 3. Rekapitulasi Kemampuan Guru Rumpun IPA Dalam Menyusun RPP Model Inkuiri Siklus I

\begin{tabular}{|c|c|c|c|c|c|c|}
\hline \multirow{2}{*}{ No } & \multirow{2}{*}{ Aspek yang dinilai } & \multicolumn{3}{|c|}{ Guru } & \multicolumn{2}{|c|}{ Rata-rata } \\
\hline & & G3 & G4 & G5 & Skor & $\%$ \\
\hline 1 & Merumuskan tujuan pembelajaran & 3 & 3 & 3 & 3.00 & 75.00 \\
\hline 2 & Mengorganisasikan bahan pembelajaran & 1 & 3 & 1 & 1.67 & 41.67 \\
\hline 3 & Menentukan strategi mengajar & 4 & 4 & 4 & 4.00 & 100.00 \\
\hline 4 & Menentukan langkah-langkah mengajar & 4 & 4 & 3 & 3.67 & 91.67 \\
\hline 5 & Menentukan alokasi waktu & 1 & 3 & 3 & 2.33 & 58,33 \\
\hline 6 & Menentukan sumber, media, dan alat & 4 & 2 & 2 & 2.67 & 66.67 \\
\hline 7 & $\begin{array}{l}\text { Menentukan bentuk, prosedur, dan alat } \\
\text { penilaian }\end{array}$ & 3 & 3 & 3 & 3.00 & 75.00 \\
\hline & Skor maksimal ideal (28) & 20 & 22 & 20 & 20.67 & 72,62 \\
\hline & $\%$ & 71.43 & 78.57 & 71.43 & & \\
\hline
\end{tabular}

Rata-rata skor tertinggi yang diperoleh guru adalah 78,57\% dan terendah $71,43 \%$.

Dari data tersebut juga diketahui bahwa terdapat aspek yang masih rendah dalam penyusunan RPP model inkuiri yaitu pada aspek pengorganisasian bahan pembelajaran $(41,67 \%)$ dan menentukan alokasi waktu $(58,33 \%)$. 
Silitonga, Jefri. S. Optimalisasi Kemampuan Guru Rumpun IPA dalam Mendesain RPP Model Inkuiri Menggunakan Supervisi Berbasis Coaching

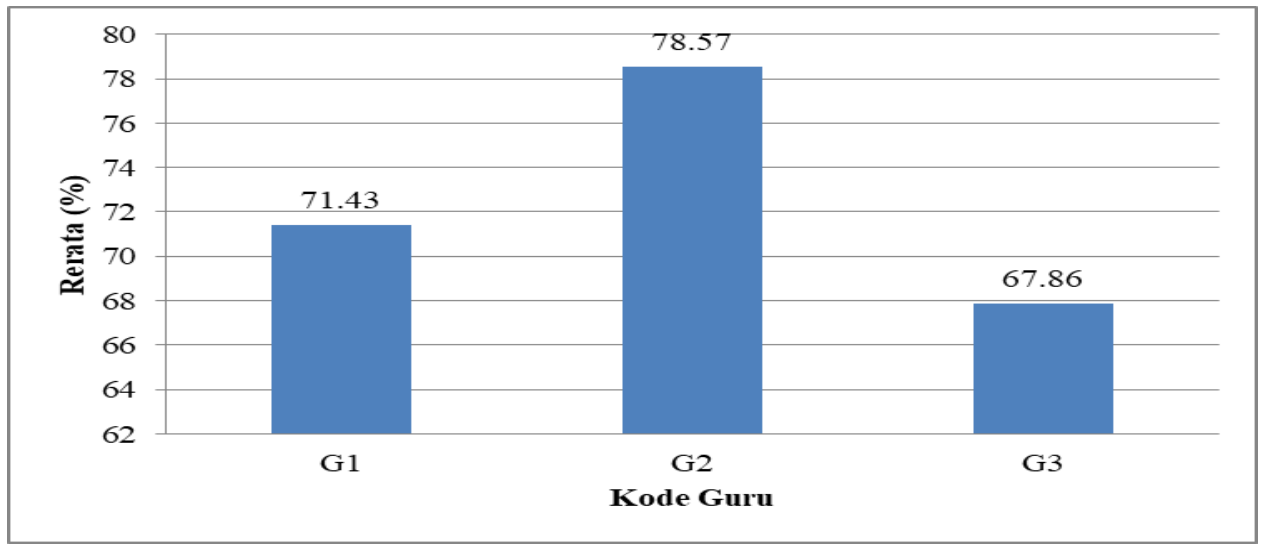

Gambar 2. Rerata Kemampuan Guru Dalam Menyusun RPP Siklus I

\section{Analisis Data Penelitian Siklus II}

Tahapan dalam penelitian ini sama dengan tahapan pada siklus I, hanya saja difokuskan pada masalah-masalah berdasarkan refleksi di siklus I seperti pada penyusunan RPP model inkuiri (aspek alokasi waktu dan organisasi bahan ajar) dan pelaksanaan pembelajaran (aspek perumusan hipotesis), yang selanjutnya dirincikan sebagai berikut;

\section{Perencanaan}

Perencanaan sesuai dengan tahapan coaching dilaksanakan sebagai berikut:

a. Melaksanakan pertemuan bersama dengan guru rumpun IPA maupun kepala sekolah/wakil kurikulum untuk membahas tentang pelaksanaan coaching siklus II.

b. Memberikan buku bacaan tentang strategi dan model pembelajaran kepada guruguru untuk lebih memahami konsep model inkuiri.

c. Memberikan referensi tentang pengembangan bahan ajar dan media pembelajaran.

d. Memberikan contoh RPP dan silabus kurikulum 2013, video pembelajaran yang menerapkan pendekatan saintifik dan model inkuiri, dan mengulas kembali tentang model inkuiri. Pada pertemuan ini topik pembahasan diarahkan pada kelemahan guru saat melaksanakan model inkuiri pada siklus pertama, yakni perumusan masalah dan hipotesis.

e. Merancang dan menyepakati jadwal pelaksanaan program coaching siklus II. Dalam hal ini alternatif waktu yang diberikan adalah lebih tentatif artinya tidak 
terlalu mengikat seperti siklus I sehingga tergantung pada guru untuk memilih waktu yangg sesuai dengan pemberitahuan terlebih dahulu kepada coach.

\section{Tindakan dan Observasi}

Pelaksanaan tindakan siklus II dilakukan dengan rangkaian kegiatan sebagai berikut;

a. Mengadakan pertemuan individual dengan guru selama 3 kali pertemuan sesuai kesepakatan. Pembagian jadwal pertemuan terhadap 5 orang guru subjek selanjutnya dirincikan pada tabel berikut ini:

Tabel 4. Pelaksanaan Pertemuan Coaching Siklus II

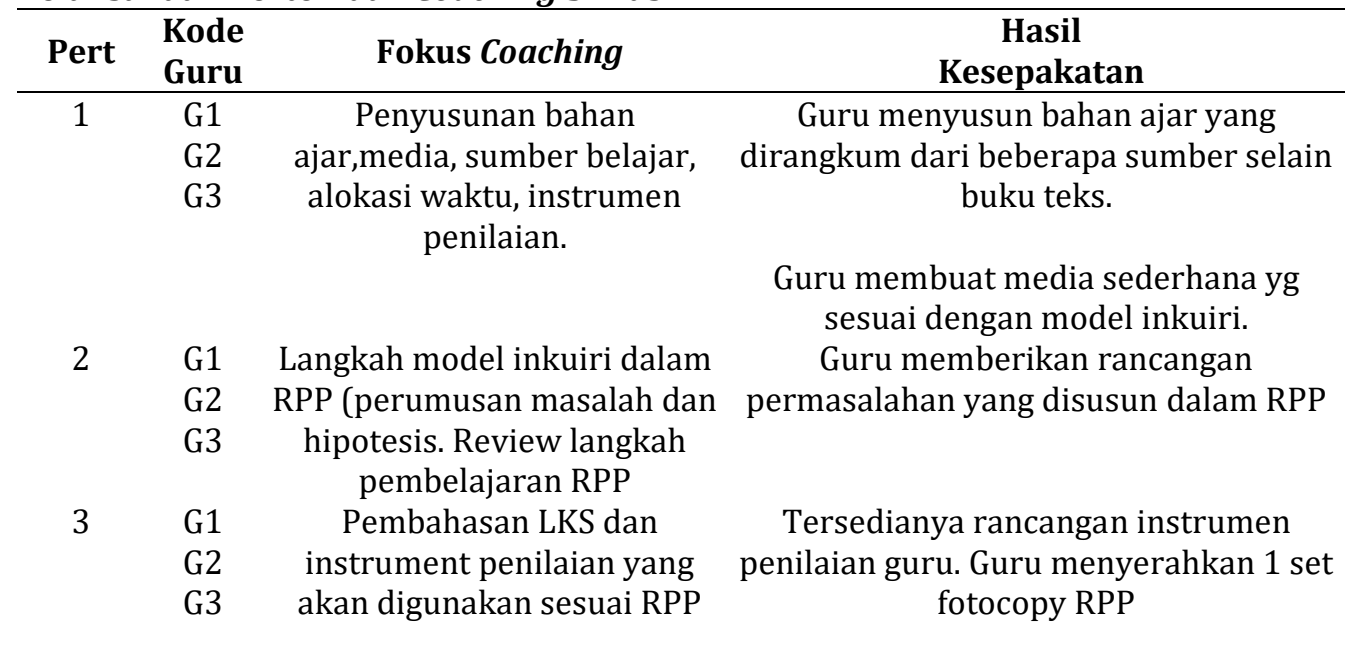

Kegiatan observasi yang dilakukan adalah:

a. Melaksanakan observasi kemampuan guru rumpun IPA dalam menerapkan model inkuiri di kelas $\mathrm{X}$ sesuai dengan jadwal tatap muka guru. Observasi dilakukan oleh peneliti bersama observer disertai dengan perekaman kegiatan pembelajaran dengan menggunakan kamera video.

b. Kemudian memberikan hasil rekaman video kepada guru, untuk dinilai dengan menggunakan lembar observasi yang sama dengan observer.

c. Meminta rekapitulasi nilai hasil belajar siswa pada masing-masing kelas guru untuk dilihat persentase klasikal siswa.

\section{Refleksi}


Silitonga, Jefri. S. Optimalisasi Kemampuan Guru Rumpun IPA dalam Mendesain RPP Model Inkuiri Menggunakan Supervisi Berbasis Coaching

Refleksi siklus II dilakukan dengan melihat catatan pengamatan dan wawancara selama kegiatan berlangsung. Hal-hal yang ditemukan selama siklus II adalah sebagai berikut:

Tabel 5. Rekapitulasi Rerata Kesesuaian Kemampuan Guru Rumpun IPA Dalam Menyusun RPP Model Inkuiri Siklus II

\begin{tabular}{|c|c|c|c|c|c|c|}
\hline \multirow{2}{*}{ NO } & \multirow{2}{*}{ Aspek Yang Dinilai } & \multicolumn{3}{|c|}{ Guru } & \multicolumn{2}{|c|}{ Rata-Rata } \\
\hline & & G1 & G2 & G3 & Skor & $\%$ \\
\hline 1 & $\begin{array}{l}\text { Kemampuan merumuskan tujuan } \\
\text { pembelajaran }\end{array}$ & 4 & 4 & 4 & 4.00 & 100.00 \\
\hline 2 & $\begin{array}{l}\text { Kemampuan mengorganisasikan bahan } \\
\text { pembelajaran }\end{array}$ & 3 & 4 & 3 & 3.33 & 83.33 \\
\hline 3 & Kemampuan menentukan strategi mengajar & 4 & 4 & 4 & 4.00 & 100.00 \\
\hline 4 & $\begin{array}{l}\text { Kemampuan menentukan langkah-langkah } \\
\text { mengajar }\end{array}$ & 4 & 4 & 4 & 4.00 & 100.00 \\
\hline 5 & Kemampuan menentukan alokasi waktu & 3 & 4 & 3 & 3.33 & 83.33 \\
\hline 6 & $\begin{array}{l}\text { Kemampuan menentukan sumber, media, } \\
\text { dan alat }\end{array}$ & 4 & 3 & 3 & 3.33 & 83.33 \\
\hline 7 & $\begin{array}{l}\text { Kemampuan menentukan bentuk, prosedur, } \\
\text { dan alat penilaian }\end{array}$ & 4 & 3 & 4 & 3.67 & 91.67 \\
\hline & Skor maksimal ideal $=28$ & 26 & 26 & 25 & 25.67 & 91.67 \\
\hline & $\%$ & 92.86 & 92.86 & 89.29 & & \\
\hline
\end{tabular}

Berdasarkan data tersebut diketahui bahwa rata-rata kemampuan guru rumpun IPA dalam menyusun RPP model inkuiri adalah 91,67\% dengan skor terendah adalah 89,29\%. Kemudian aspek yang terendah adalah pengorganisasian bahan pembelajaran, menentukan alokasi waktu, dan menentukan sumber, media dan alat namun telah mencapai minimal 83,33\%.

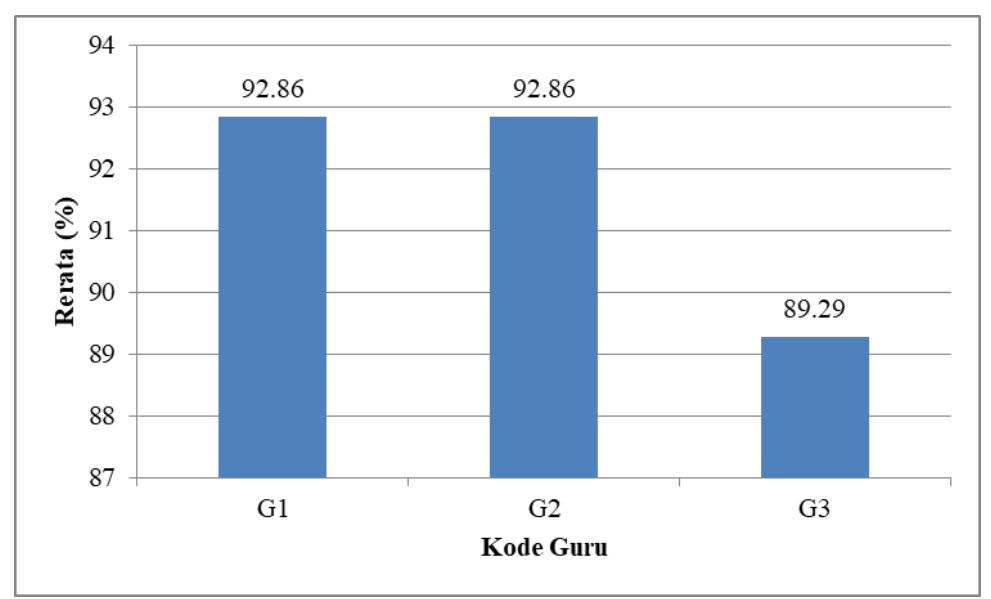

Gambar 3. Rerata \% Kemampuan Guru Menyusun RPP Siklus II

Refleksi/ umpan balik yang dilakukan bersama dengan guru adalah berdasarkan data observasi yang telah ada. Pada refleksi ini juga diminta komentar dari pihak observer sebagai bahan masukan kepada guru. Selama kegiatan umpan balik terungkap bahwa; 
1. Guru merasa sudah mulai terbiasa dengan langkah-langkah dalam model inkuiri, hanya saja masih ada kejanggalan pada saat mengajak siswa untuk merumuskan hipotesis sebelum melakukan kegiatan pengumpulan data, sehingga guru langsung menyebutkan hipotesis tersebut.

2. Guru merasa puas dengan aktivitas siswa yang aktif selama kegiatan berlangsung.

3. Guru merasa masih belum bisa mengelola waktu dengan baik pada langkah pembelajaran, sehingga pada pertemuan selanjutnya direncanakan untuk membuat kesepakatan rentang waktu kegiatan dengan siswa pada saat kegiatan pendahuluan, diharapkan akan ada komitmen antara guru dan siswa dalam pembagian waktu kegiatan.

Penelitian ini dilaksanakan dalam 2 siklus tindakan dengan menggunakan supervisi akademik berbasis coaching. Coaching merupakan contoh pendekatan yang baik dalam supervisi, sebab secara informal memahami kebutuhan dan ketertarikan guru dan cukup formal untuk menjamin standar kesepakatan pembelajaran yang baik. Coaching dilakukan dengan menggunakan prinsip kerjasama, berbagi, menjembatani gap, formal dan informal, kemitraan, motivasi, fokus, saling percaya, dan rasa hormat (Kemdikbud, 2013).

Pada siklus I diketahui bahwa rerata kesesuaian kemampuan guru dalam menyusun RPP model inkuiri adalah $72,62 \%$, dan pada siklus ini masih terdapat skor rendah pada aspek pengorganisasian bahan ajar, penentuan alokasi waktu, dan pemilihan sumber/media ajar. Hal ini disebabkan ada guru yang tidak menjabarkan bahan ajar secara sistematis dan sesuai kaedah ilmiah, tidak membagi waktu dalam setiap langkah secara proporsional, dan juga tidak mengembangkan penilaian sesuai dengan tujuan pembelajaran.

Pada siklus II terjadi peningkatan rerata kesesuaian kemampuan guru rumpun IPA menyusun RPP model inkuiri menjadi 91,67\% meskipun masih terdapat skor terendah pada aspek pengorganisasian bahan ajar (83,33\%). Hal ini dikarenakan terdapat guru yang mencantumkan bahan ajar yang tidak sesuai dengan kaedah ilmiah yakni tidak dijabarkan dari yang umum ke yang khusus beserta contoh yang relevan. Namun, secara 
Silitonga, Jefri. S. Optimalisasi Kemampuan Guru Rumpun IPA dalam Mendesain RPP Model Inkuiri Menggunakan Supervisi Berbasis Coaching

keseluruhan kemampuan guru rumpun IPA dalam menyusun RPP model inkuiri telah mencapai indikator keberhasilan tindakan yakni di atas $85 \%$.

\section{SIMPULAN}

Hasil observasi awal dengan menelaah perangkat pembelajaran yang telah disusun oleh guru diperoleh data kesesuaian sebesar 60,71 \% terhadap indikator-indikator penulisan RPP, dengan indikator terendah adalah penggorganisasian bahan ajar. Setelah melakukan tindakan supervisi berbasis coaching pada siklus I diperoleh kesesuaian sebesar 72,62\% dengan indikator yang perlu diperhatikan adalah pada pengorganisasian bahan ajar dan penentuan alokasi waktu. Pada siklus II, pada siklus ini terjadi peningkatan kemampuan guru menncapai 91,67\% dengan indikator terendah yang sama yakni pada pengorganisasian bahan ajar dan waktu. Sehingga dapat disarankan, bahwa supervisi akademik berbasis coaching dapat digunakan sebagai salah satu model alternatif baik oleh pengawas sekolah, kepala sekolah, dan guru senior pada program guru induksi.

\section{DAFTAR PUSTAKA}

Aqib, Z \& Rohmanto, E. (2007). Membangun Profesionalisme Guru dan Pengawas Sekolah. Bandung: Yrama Widya.

Joyce, D. (2011). Models Of Teaching. (Achmad Fawaid, Ed.) (Kedelapan). Yogyakarta: Pustaka Pelajar.

Kemdikbud. (2013). Bahan Pelatihan Implementasi Kurikulum 2013: Supervisi Pembelajaran Pada Kurikulum 2013 Terhadap Guru dan Kepala Sekolah. Badan Pengembangan Sumber Daya Manusia Pendidikan dan Kebudayaan dan Penjaminan Mutu Pendidikan Kementerian Pendidikan dan Kebudayaan. Jakarta.

Koes, S. (2003). Strategi Pembelajaran Fisika. Malang: Universitas Negeri Malang.

Puskur Balitbang Depdiknas. (2007). Kajian Kebijakan Mata Pelajaran IPA. Jakarta.

Riandi, D. (2008). Developing Of Video-Based Coaching Package: Results Of The Second Year Research Project. Paper to be presented at "The 2nd International Seminar on Science Education." Bandung.

Sagala, S. (2010). Supervisi Pembelajaran dalam Profesi Pendidikan. Bandung: Alfabeta.

Sanjaya, W. (2011). Strategi Pembelajaran Berorientasi Standar Proses Pendidikan (Cetakan Ke). Jakarta: Kencana Prenada Media Group.

Sergiovani, T dan Starratt, R. (2007). Supervision : A Redefinition. New York: Mc Graw-Hill International Book Company.

Soetjipto;, \& Kosasi. (1999). Profesi Keguruan. Jakarta: Rineka Cipta.

Suhatman. (2013). Implementasi Pembelajaran Salah Kaprah Di Madrasah Wilayah Kerja Balai Diklat Keagamaan Jakarta. Retrieved from http://bdkjakarta.kemenag.go.id/index.php?a=artikel\&id=847.

Sukardi. (2005). Metodologi Penelitian Pendidikan : Kompetensi dan Praktiknya. Jakarta: Bumi Aksara.

Trianto. (2011). Model-model Pembelajaran Inovatif Berorientasi Konstruktivistik Konsep, Landasan Teoritis Praktis dan Implikasinya. Jakarta: Prestasi Pustaka Publisher.

Widodo, D. (2011). Pengembangan Paket Program Coaching Berbasis Video. Cakrawala Pendidikan, $X X X(1)$.

Witarsa, R. (2011). Analisis Kemampuan Inkuiri Guru Yang Sudah Tersertifikasi Dan Belum Tersertifikasi Dalam Pembelajaran Sains SD. Jurnal Edisi Khusus, (2). 